\title{
EU STRATEGIC INTERESTS IN KAZAKHSTAN IN THE CONTEXT OF GEOPOLITICAL AND GEO-ECONOMIC CHANGES IN THE REGION WITH FOCUS ON CHINA
}

\section{a'KRISTÍNA DRIENIKOVÁ, 'L'UBICA ZUBALOVÁ}

University of Economics, Faculty of Commerce, Dolnozemská 1, Bratislava, Slovak Republic

email: ${ }^{a}$ kristina.drienikova@euba.sk, ${ }^{b} l u b i c a . z u b a l o v a @ e u b a . s k$

This paper is a part of two research projects of the Ministry of Education, Family and Sports of the Slovak Republic: VEGA No. 1/0777/20: Belt and Road initiative opportunity or threat for the EU and Slovak export competitiveness?; and VEGA No. 1/0039/20: The Importance of the Eurasian Economic Union for Shaping of EU Trade Strategies (with Implications for Slovakia).

Abstract: Kazakhstan has an important position as the EU's main trading partner in Central Asia and the EU has been its largest trade partner as well as the largest source Central Asia and the EU has been its largest trade partner as well as the largest source of foreign direct investment. The importance of China as trade and investment partner is rising, on the contrary, the EU's share is declining. Even though there remains plenty of scope for further growth, mutual relations and cooperation are influenced by ine paper evaluates the position of the EU and its strategic interests in Kazakhstan in the context of geopolitical and geo-economic changes in the region based on the assessment of the trade and investment position of the EU in comparison with the position of China.

Keywords: Belt and Road Initiative (BRI), China, EU, Eurasian Economic Union (EAEU), investment, Kazakhstan, trade.

\section{Introduction}

Kazakhstan, the world's largest landlocked country, due to its location, vast landmass and energy reserves is not only a subject but also an object of geopolitical interests. Situated in the middle of the trade routes from China to Europe with significant transport and logistics importance, the country is building strong partnership to the East (China), to the West (EU) and within the region (especially as a member of Eurasian Economic Union)

It is the largest and most advanced (upper middle-income country) economy in Central Asia with strong position in the energy sector thanks to the second largest oil reserves in Eurasian region (after Russia), significant reserves of other nonferrous metals, gold, uranium etc., as well as in agricultural sector as one of the top wheat exporters and producers in the world (Fehér \& Fieldsend, 2019). Thanks to its geographical location it is considered as a linchpin of Eurasia and therefore, its huge potential should be considered not only in terms of natural resources abundance, but also in terms of its geostrategic location and thereafter possibilities of developing transcontinental routes, in particular as a transit country in EuroAsian (especially between Europe and China) trade and economic relations (Kašt’áková et al., 2019).

The highly volatile geopolitical situation has brought significant and unexpected changes that affect the position of the EU in Central Asia and Kazakhstan. Since 1990s Kazakhstan officially pursues a "multi-vector" foreign policy, tries to maintain good and mutually beneficial trade, investment, and diplomatic relations with all the great actors engaged in Central Asian region, especially with Russia, China, the EU, and the United States (Zogg, 2019; Vanderhill et al., 2020) as well as balance its investments needs in energy, transport, or retail (Pieper, 2020).

Regarding the country's dependence on energy and raw materials exports, it has strong ties with the nearest neighbours, Russia, and China. Kazakhstan is a founding member of the Eurasian Economic Union (EAEU) and the Shanghai Cooperation Organization. As EAEU members Russia and Kazakhstan strive for close cooperation and deeper integration. The EAEU also established a legal framework with China, the agreement on trade and economic cooperation entered into force in October 2019 (EEC, 2019). Whereas Russia is considered as the most influential actor in Kazakhstan, China comes second. Paradoxically, in terms of cultural appeal, Kazakhstan is more oriented towards Europe. For Russia, Kazakhstan, as a part of Central Asia, area of its closest foreign policy interests, is strategically important in terms of security, energy, and economic cooperation. Similarly, these areas predominate in Chinese as well as European interests. However, the EU is not a key player in the region, it cannot compete with Russia, China, or the US in terms of hard power policy (Konopelko, 2017), its importance is universally acknowledged as region's economic partner (Cornell \& Engwall, 2017) and thanks its soft power policy (promotion of democracy, rule of law, respect to civil liberties etc.) it can play a constructive role as an alternative to Russia or China. On the other hand, the EU perceives Kazakhstan as a partner for promoting peace and security in the wider region. Kazakhstan tends to deepen mutual relations and cooperation with the EU, it is also the result of its efforts to increase openness and more active participation in international organizations and regional integration.

The rise of China's economic power and assertive foreign policy, along with its Belt and Road Initiative (BRI) have changed the balance of power in Central Asian region, what has among other things led to growing concerns in Kazakhstan about its influence and power (Vanderhill et al., 2020). Kazakhstan is among the top ten beneficiaries of Chinese non-concessional finance. China is also more visible in Kazakhstan compared to surrounding countries. BRI project in Kazakhstan, unlike in neighbouring countries, is coordinated with its national development strategy “Nurly Zhol”.

\section{Literature review}

There is an increasing interest among academics as for the trade, investment, political and economic impact of increasing Chinese influence, engagement regarding its Belt and Road Initiative development. The impact of geopolitical changes on the EU's foreign trade relations with Kazakhstan and with the Central Asian region was examined in detail by Kaštáková et al. (2019). As for the BRI implications for Europe, these has been discussed by Cornell and Swanström (2020).

Some authors have dealt with the effects of the BRI in Central Asia or Kazakhstan. Bitabarova (2018) has shown that there is a complementarity of mutual Chinese and Kazakh interests and trade, however the economic cooperation strengthening has not let to improvement of perceptions of China in Kazakhstan. Pieper (2020) examines Kazakhstan's position in relations between China (BRI) and Russia (EAEU), and critically analyses implications of the BRI on the socio-political structure in Kazakhstan. Pantucci (2019) discuss China's relations with Central Asia via Belt and Road Initiative. Nabiyeva (2019) draws attention on implications and risks of Chinese cooperation as a consequence of lack of transparency of Chinese loans, financing of unsustainable projects, and non-respect of environment and human rights. The author reminds the possibility that "Chinese cooperation does not necessarily contribute to higher economic growth, business development and employment” (p. 6). Perceptions arising from China's presence in Kazakhstan are also discussed by Pieper (2020); Vakulchuk and Overland (2019) discuss the perception of China among local actors in Central Asia analyzing economic cooperation, infrastructure, and educational projects; and Laruelle (2018) examines the effects of China's soft power diplomacy in Kazakhstan.

Other scholars have focussed their attention on the relations between the BRI and EAEU. Shakhanova and Garlick (2020) conducted a comparative analysis of the perceptions concerning the coordination of the BRI and EAEU and concluded that mutual coordination would rather be more difficult. CzerewaczFilipowicz (2019) has assessed the potential of the EAEU as a transport corridor within the BRI.

From the point of view of Kazakhstan's relations with the most important partners in connection with geopolitical changes Vanderhill et al. (2020) confirm the effectiveness of 
Kazakhstan's multi-vector foreign policy in protecting its independence and achieving its goals and argue that natural resources' wealthiness served as a great leverage in relations with China, the EU and Russia (use their competing interests and avoid economic dependence on any of them) and to achieve its foreign policy success.

\section{Methodology}

The aim of the paper is to evaluate the position of the EU and its strategic interests in Kazakhstan in the context of geopolitical and geo-economic changes in the region based on the assessment of the trade and investment position of the EU in comparison with the position of China.

This contribution is a part of authors' broader research in relations between the EU and the Eurasian region, impact of geopolitical and geo-economics changes, increasing position of China, and its BRI initiative investments on the EU agenda in the region. Therefore, in this case we decided to focus the comparison of the EU position only on position of China as one of the main strategic partners for Kazakhstan, especially due to increasing trade and investment relations (BRI). We focused on comparing the positions of the EU and China as trading partners of Kazakhstan, while also comparing the commodity structure of Kazakhstan's trade with both partners and evaluating the level and intensity of mutual trade. Subsequently, we compared the position of the EU and China as investors in the country.

To assess and compare the level and intensity of Kazakhstan's trade cooperation with the EU and China - as well as vice versa - we used trade intensity index (TII). The purpose of TII is to determine whether the value of trade between two countries/regions is greater or smaller than it would be expected based on their importance in the world trade. It is defined as the share of one country's exports going to a partner divided by the share of world exports going to the partner (World Bank, 2010). It is calculated as:

$$
T I I i j=\frac{\left(\frac{x i j}{X i t}\right)}{\left(\frac{x w j}{X w t}\right)}
$$

(1)

where $x_{i j}$ is the value of country i's exports to partner country $j$, $X_{i t}$ is the value of total exports of the country $i$; $x_{w j}-$ value of world exports to country j, and $\mathrm{X}_{\mathrm{wt}}$ is the world exports' value.

The TII values range from 0 to. $+\mathrm{A}$ value greater than 1 indicates a relationship more intense than the world average for the partner country (World Bank, 2013). If the index is more than 1 , it indicates a more intensive trade between the partner countries than expected given their position in world economy; and if the TII is less than 1 , the intensity of trade is at lower level, than it would be expected.

For our analysis and the calculation of TII, we used foreign trade data from International Trade Center (ITC), the Trade Map database. The monetary units of this database are expressed in USD. From the point of view of Kazakhstan, all values concerning trade flows, FDI and external debt are expressed in USD. As far as the EU is concerned, for the period under review we calculated with data for the 27 member states (EU27).

\section{Results and discussion}

Energy has been the driving force for cooperation since the establishment of Kazakhstan's relations with both the EU and China. Up to two-thirds of EU investments in Kazakhstan go directly to exploration and extraction of natural resources (Konopelko, 2018). The EU is pushing for diversification of supply and Kazakhstan's potential is not yet fully exploited. Besides energy, the Central Asia's development as an important trade corridor has created a new major vector for mutual economic relations. In this respect, Kazakhstan in terms of its geographical location, business environment and economic policy improvements, is becoming more important especially in connection with Chinese project of revitalizing the Silk Road trade routes. Since 2013, when BRI was originally announced in Astana (Nur-Sultan), Kazakhstan has been heavily politically involved in the project. The Kazakhstan's role as the landlocked country will be particularly important for Silk Road Economic Belt (SREB), the land part of the BRI. According to Pieper (2020) the BRI helps break Kazakhstan's landlocked country status and "shapes new geopolitical realities" as well (p. 6).

\subsection{Kazakhstan's trade relations with the EU and China - comparison}

Kazakhstan is the largest EU trading partner of the Central Asia, accounting for more than $85 \%$ of the overall trade between the EU and the region. However, for the EU the Central Asian region is rather insignificant trade partner, it accounted just for $0.7 \%$ of the EU external trade in 2019 and Kazakhstan was on the $31^{\text {st }}$ place as the EU trading partner $(0.6 \%$ of the EU trade). On the other hand, the EU is still the main trading partner (especially as an export market) for Central Asia (24.1\% of the region's external trade), closely followed by China (22.3\%) and Russia (20.2\%) (European Commission, 2020a,b).

Relations between the EU and Kazakhstan can be described as close and mutually beneficial. There is no unified approach, however, to Kazakhstan or Central Asia as a whole, among the EU member states, thus it has been difficult for the EU to induce significant change in country's approach to the values promoted by its Western partners (respect for civil liberties, media freedom, fair elections) (Zogg, 2019). The EU has had an important role in emphasizing its norms and values which have been promoted as important conditions for mutual relations in its approach to Kazakhstan and included in key bilateral documents and agreements, and EU strategy on Central Asia as well (Yesdauletov et al., 2017) which emphasizes the EU engagement with Central Asian countries in protection and promotion of human rights, rule of law and fundamental freedoms.

Mutual relations are governed by the Enhanced Partnership and Cooperation Agreement (EPCA), which entered into force in March 2020 and provides a framework for reinforced political dialogue, trade relations and cooperation in variety of areas. The EPCA replaced the Partnership and Cooperation Agreement (signed in 1994) which became obsolete and no longer reflected the development of both partners and new geopolitical reality. The EPCA agreement puts strong emphasis on democracy, rule of law, human rights, fundamental freedoms, civil society cooperation.

However, mutual relations have been negatively affected by deteriorated EU relations with Russia (since 2014 due to crisis in Ukraine). Moreover, the EU and Russia compete for increasing their influence in post-Soviet space and Kazakhstan is highly dependent on both. Russia is the second largest trading partner accounting for more than $20 \%$ of Kazakh foreign trade; shares the second longest land border in the world; both countries are members of the EAEU, and Russia serves as transit territory for almost all of Kazakhstan's exports to the EU. Thus, it is necessary for Kazakhstan to find a balance between the divergent interests of the EU and Russia (Yesdauletov et al., 2017). For example, due to transit restrictions for the EU and Ukrainian goods supply introduced by Russia via its territory to Kazakhstan, as part of its sanctions, Kazakhstan has become a big looser although the country does not share the same political tensions with the EU or Ukraine as Russia and does not aspire to a geopolitical role (Balás et al., 2018). Figure 1 provides information about the development of trade relations between Kazakhstan and the EU. 
Figure 1: Kazakhstan's trade in goods with the EU27 (2007 2019, in million USD)

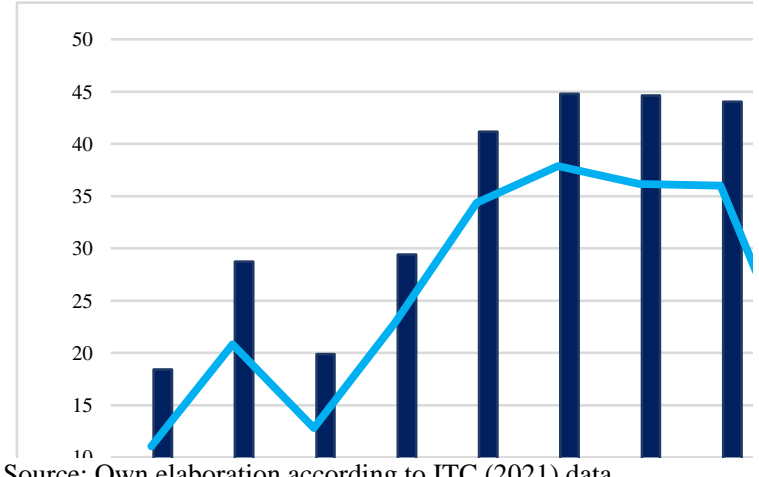

Source: Own elaboration according to ITC (2021) data.

Kazakhstan has an active trade balance in trade with the EU. Since 2009 mutual trade increased dramatically reaching its highest levels between 2012 and 2014, to more than 51 billion USD, especially on the exports side thanks to favourable world market oil prices. Due to geopolitical tensions in the region caused by the Ukrainian crisis and significantly worsened situation in relations between the EU and Russia, as well as due to fall in world oil prices, mutual trade decreased dramatically in 2015 and 2016. The EU's share in Kazakh external trade fell to $37 \%$. After 2-years growth trend, in 2019 mutual trade decreased again. Compared to 2018, imports from the EU decreased by $2.7 \%$ and exports to EU fell by almost $20 \%$. However, according to the EU statistics, imports from Kazakhstan declined by $8.9 \%$, whereby exports of goods to Kazakhstan increased by $7.9 \%$ (European Commission, 2020b).

As regards the commodity structure, Kazakhstan strives to diversify its economy, as well as its trading partners, however, it is still highly dependent on European partners and hydrocarbon exports. The country's exports to the EU are limited to a few commodities, particularly oil and metals, whereby the imports from the EU consist of industrial products with transport and machinery having the largest share, followed by manufactures and chemicals (Table 1). The EU has a strong interest in modernisation and diversification of Kazakh economy, however, even though cooperation has expanded into many areas (including energy, transport, and agriculture), there remains plenty of scope for further growth. Compared to Russia or China, it has lesser political influence in Kazakhstan, but maintains significant economic influence.

Kazakhstan's strategic aim is to diversify and modernize the economy. The priority sectors include metallurgy, petroleum and chemical industry, mechanical engineering, food, and construction industries. The state program of intensive industrial and innovative development (SPIID) highlights the model of economic development with manufacturing as the main driver of the industry's growth. The program is complemented by "Nurly Zhol" (the "Bright Path") economic policy which focuses primarily on the infrastructure in seven areas (Kazakhembus.com, n.d.). "Nurly Zhol” was announced in 2014 as a reaction on decreased oil prices leading to economic slowdown, related decrease of trade and FDI with China (Aitzhanova, 2019).

Mutual China-Kazakhstan economic relations, established long before the BRI announcement, have become much more diversified with BRI cooperation (Aitzhanova, 2019). Kazakhstan announced independence in 1991 and China recognised the sovereign state in the same year, establishing diplomatic relations in 1992. Chinese investments, principally in fossil fuels, participated in exploitation of oil already in 1997, when Chinese National Petroleum Corporation became 60\% shareholder of Kazakhstan's National Petroleum Corporation. In 2013 China announced the idea of land based SREB to support transnational links between China and Eurasian region. SREB or BRI suitably complemented "Nurly Zhol”. In 2014 countries signed formal agreement "Joint Construction of the Silk Road Economic Belt”, in 2015 an agreement on aligning Kazakh and Chinese (SREB) initiatives was approved (Pieper, 2020), and China has become one of the partners of the infrastructure program. As of 2019 Kazakhstan and China are permanent comprehensive strategic partners. China wants to be perceived as reliable partner, tolerant to Muslims, peaceful as an alternative to Russia or western countries but without political goals, though with common objectives and benefits - development and economic growth.

For Kazakhstan China is the third largest trade partner accounting for $15 \%$ of Kazakh foreign trade, which is less than half of the value traded with the EU (31.5\% of Kazakh trade). Trade balance is positive, Kazakh exports to China exceed imports (European Commission, 2020b).

More detailed information on trade in goods between China and Kazakhstan is in Figures 2, 3 and Table 1. Exports to China ranged between $10.3 \%$ (in 2018) to $18.5 \%$ (in 2011). One third (36\%) of the exports in 2019 consisted of mineral fuels, oils, and distillation products. Kazakhstan's exports to China were significant between 2010 and 2013, which corresponds to high oil prices (oil prices declined at the end of 2014). Imports from China oscillated between $10.7 \%-17.8 \%$, reaching almost $17 \%$ of all Kazakh imports in 2019. Up to 84\% of Kazakhstan exports to China are fuels, minerals and metals and the country understand the need to diversify economy in order to overcome its dependence on raw materials.

Figure 2: Kazakhstan's trade in goods with China (2007 - 2019, in million USD)

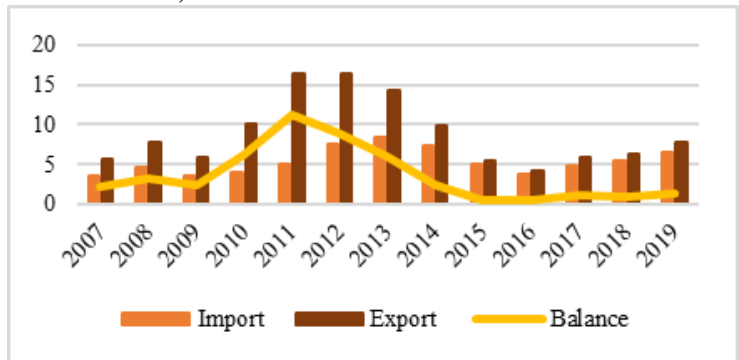

Source: Own elaboration according to ITC (2021) data.

Trade with the EU represented almost one third of the country's total external trade in 2019, making the EU its principal trade partner. However, we can observe a decrease in EU's share by 7.5 percentage points compared to 2018 (Figure 3).

Figure 3: The development of the EU and China share in Kazakhstan trade (in \%)

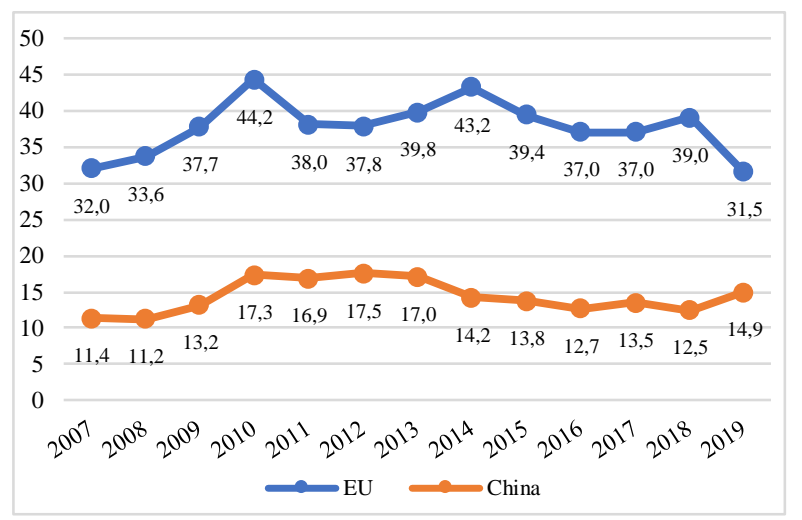

Source: Own elaboration according to ITC (2021) data.

Between 2010 and 2013 China accounted for about 17\% of Kazakhstan's foreign trade, then its share fell to an average of 13\% between 2014 and 2018. In 2019 we can observe a slight increase ich China's share. The EU's share has also been declining since 2014 (except for a slight increase in 2018), and 
in 2019 it decreased by almost 8 percentage points. Comparing Kazakh trade with the EU and China as for its commodity structure, we can conclude that is very similar as for imports. Machinery and mechanical appliances ('84) is the top import commodity group accounting for more than one fifth of Kazakh imports from the EU and China as well. Electrical machinery and equipment ('85) similarly, account for almost $20 \%$ of imports from the EU and China. Thus, equally, $40 \%$ of Kazakhstan's imports both from the EU and from China are manufactured goods (machinery and electrical equipment). On the Kazakh exports side, mineral fuels, and oils ('27) account for $94 \%$ of all exports to the EU, whereby exports to China are more diversified - with mineral fuels and oils accounting for $36 \%$, copper and articles thereof for $20 \%$, ores and slags for $14 \%$, iron and steel for $11 \%$ of exports to China.

Tab. 1: Commodity structure of Kazakhstan's trade with the EU and China - breakdown to top 5 commodity groups, HS2 in 2019 (value in million USD)

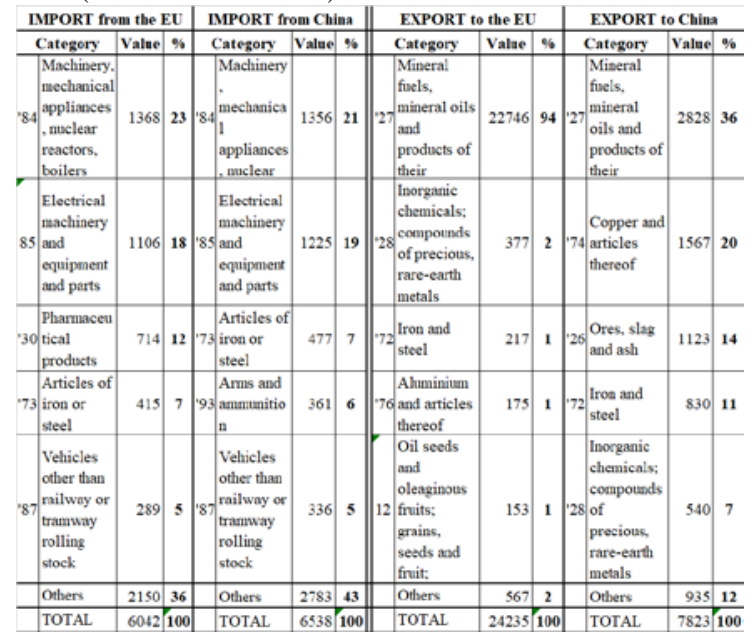

Source: Own elaboration according to ITC (2021) data

Kazakhstan covers a significant part of the EU energy demand as the third most important oil supplier (6\% of EU oil demand) after Russia and Norway. Similarly, it is the single largest supplier to EU nuclear energy industry and accounts for more than $21 \%$ of the EU uranium demand. Thus, Kazakhstan significantly contributes towards the diversification of energy sources supply for the EU (EEAS, 2020b).

We used the TII to evaluate the size of Kazakhstan's trade with EU27 and with China as well as the to evaluate trade intensity of the EU and China's trade with Kazakhstan. Figure 4 shows the trend of trade intensity in the period under review.

Figure 4: Development of TII between Kazakhstan and the EU and between Kazakhstan and China, as well as vice versa in 2007-2019

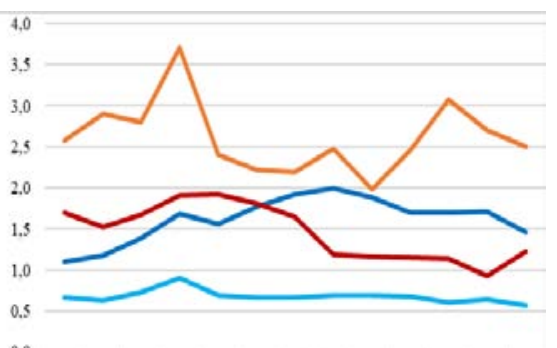

$0,0 \longdiv { 2 0 0 7 2 0 0 8 2 0 0 9 2 0 1 0 2 0 1 1 2 0 1 2 2 0 1 3 2 0 1 4 2 0 1 5 2 0 1 6 2 0 1 7 2 0 1 8 2 0 1 9 }$

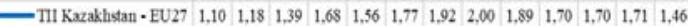

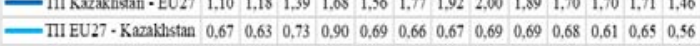

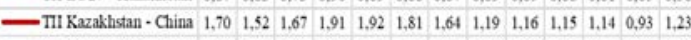

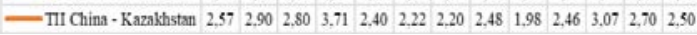
Source: Own elaboration according to ITC (2021) data.

The value of TII Kazakhstan-EU27 as well as the value of TII Kazakhstan-China (with one exemption in 2018) was more than
Therefore, we can claim big activities of Kazakh exporters on the EU and China's markets. The highest value of Kazakhstan's trade intensity with the EU was reached in 2014, however since then the index has been declining. According to Kaštáková and Barinková (2019) this decline should be caused by fall in world oil prices. Despite that, it did not drop below 1 during the period under review. That means the Kazakh trade with the EU was more intense than it was expected considering the EU position in the world and that the EU is an important trade partner for Kazakhstan.

On the other hand, the trade intensity with China reached its highest values in 2010 and 2011 and in 2014 decreased significantly. It increased again in 2019. The average value of Kazakhstan's trade intensity with China (1.46) was 0.16 below the average value of trade intensity with the EU27 (1.62). It indicates intensive trade from Kazakhstan to China.

As for the trade intensity of the EU trade with Kazakhstan it reached values lower than 1 during the whole period under review. This means that for the EU, Kazakhstan is not such a trading partner as would be expected based on its position in the world economy, which is also confirmed by its position in the EU's foreign trade.

On the other hand, the trade intensity index of China and Kazakhstan is high, reaching values exceeding 2 (except for 2015). The highest values were reached in 2010 and 2017 (3.71 and 3.07 respectively), indicating China's high export activity to Kazakhstan.

\subsection{Investments}

Kazakhstan accounted for $78 \%$ of gross FDI inflow to Central Asia between 2007 and 2019 (Yergaliyeva, 2020). The EU is one of the principal sources of FDI in Central Asia, whereby Kazakhstan has benefited from substantial inflows of these FDI, especially thanks to its extractive and exploration industries. Although the FDI flows have become more diversified, this sector remains as a dominant source of FDI (Bossuyt, 2015). Similarly, China, in comparison to the EU as a relative latecomer, has become an important source of FDI in Central Asia with the biggest share going to Kazakhstan as well. China's FDI in the region are concentrated in transport infrastructure and the extractive and mining industries (Bossuyt, 2015).

Since 2007, the total amount of FDI (inward stock) to Kazakhstan almost doubled in 2010 and in 2016 exceed the amount of 140 billion USD. As for the FDI inflows the highest levels of more than 13 billion USD were reached in 2008, 2009, 2011 and 2012, however, in the subsequent years, inflows gradually (except in 2016) declined from 10.3 billion in 2010 to 3.1 billion USD in 2019. According to World Investment Report 2020 the FDI flows to Kazakhstan decreased in 2019 by $17 \%$ in comparison to 2018. The largest greenfield project in Kazakhstan was the announcement of 600 billion USD carbide plant of Chinese North Huajin Chemical Industries (UNCTAD, 2020). Ongoing large projects in metal mining continue to attract the majority of FDI inflows, mining and metallurgy is still the most successful sector for FDI in Kazakhstan accounting for $56.3 \%$ (13.6 billion USD) of the FDI inflows in 2019. This is followed by FDI in manufacturing (14.3\%), in wholesale or retail trade $(12.3 \%)$ and transportation sector accounted for almost 5\% of total FDI inflows (Kazakh invest, 2019). The FDI into extraction of crude petroleum and natural gas alone lured $50 \%$ of all FDI inflows in 2019. However, due to weakened demand for commodities and low oil price the UNCTAD revised downward prospects for natural resource based FDI inflows in 2020 (UNCTAD, 2020).

When considering the gross FDI inflows to Kazakhstan in 2019, the Netherlands (30\%), USA (23\%), Switzerland (9\%), China (7\%), and Russia (6\%) are the top largest FDI sources to Kazakhstan together accounting for $75 \%$ of all gross FDI inflows in 2019. The EU has been by far the largest investor in Kazakhstan, accounting for $42.5 \%$ of total gross inflows in 2019 
(10 369 million USD), whereby Netherlands as the dominant investor in Kazakhstan (30.2\%) accounts for more than $70 \%$ of all EU gross inflows. The second major EU investor (10\%) has been France (1 072 million USD in 2019) (National Bank of the Republic of Kazakhstan, 2021).

Therefore, to assess the position of the EU and China, it is appropriate to compare China with the Netherlands and France, which together account for more than $80 \%$ of the EU's FDI in Kazakhstan (Figure 5). Gross inflows from Netherlands increased rapidly to its record values of more than 8 billion USD in 2011 and 2012, however since then, the value of the inflow has declined, but has remained above 5 billion USD. The highest inflows from China were recorded in 2012 and 2013 (2415 million USD and 2246 million USD respectively), but haven't exceed 2.5 billion USD. In 2015, the Chinese inflows declined (833 million USD) but since 2016, when 55 (27-28 billion USD) new industrial projects were announced, FDI have grown slowly again.

Figure 5: Gross FDI inflows to Kazakhstan from the Netherlands, France, and China (in million USD)

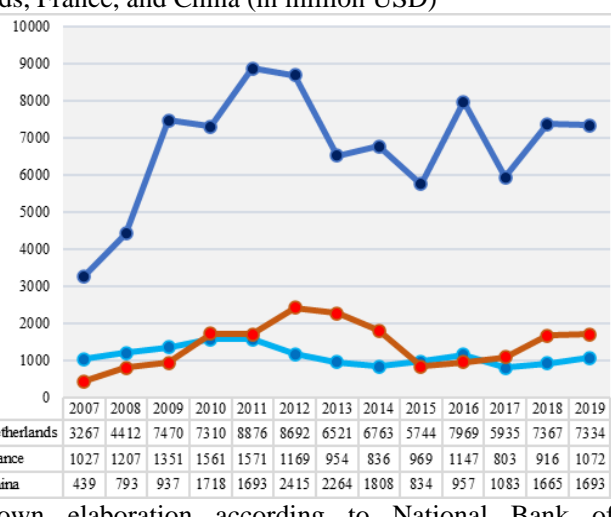

\begin{tabular}{cc|c|c|c|cccccccccc}
\hline$\rightarrow$ China & 439 & 793 & 937 & 1718 & 1693 & 2415 & 2264 & 1808 & 834 & 957 & 1083 & 1665 & 1693 \\
\hline Source: own elaboration according to National Bank of
\end{tabular} Kazakhstan (2021) data.

Energy sector lured the main share of FDI inflows from the EU companies (especially Royal Dutch Shell or French Total) which have provided the Kazakh energy sector of crucial technology. Overall, $7 \%$ of gross FDI inflows are from China. The investment activities of China intensified after the launch of BRI initiative, and moreover, Chinese lending and investments became more diversified (Kley, 2020). China has adopted new economic model for Eurasian region, investing less in infrastructure and spreading the risks to different industries manufacturing, solar and wind farms, as well as agriculture. The list of mediated BRI project (55 projects total of 27.6 billion USD) was made public only in 2019, within which half of the investments flows into the hydrocarbons (13.9 billion USD), $22 \%$ into mining and metallurgy (5.98 billion USD), $9 \%$ to energy (2.38 billion USD), 4\% into machine building (1.16 billion USD), $1 \%$ in food industry ( 0.39 billion USD) and $14 \%$ into others (3.77 billion USD) (Kazakh Invest, 2019). Out of announced 55 projects:

- 15 projects are completed (3.9 billion USD: 50\% in petrochemicals, $22 \%$ in mining and metallurgy). Although the vast majority of the projects is not in line with national plan to diversify, the first promising companies were created in auto assembly industry (1.1 billion USD) and camel milk processing (22 billion USD) (Mardell, 2020).

- 11 projects are under construction and,

- 29 are in planning process and $10 \%$ of them should be in production of finished consumer products (Kazakh Invest, 2019).

As for the Chinese loans to Kazakhstan these are, compared to those from the EU, unconditional, but also non-transparent in terms and conditions. China is not a member of OECD consensus and therefore is not obliged to report official loans as it is required by other export credit agencies. Almost all investments are realised by state-owned companies and usually have minimum $50 \%$ of Chinese content; loans are partly financial aid and China requires oversight of the project (Railway from Dostyk to Aktau, port of Aktau extension, Kuryk port). Kazakhstan's debt to China is the largest in the region (in absolute terms), but lowest as a percentage of GDP. Total debt (declining) of 10621 million USD was significantly lower compared to the debt to EU27 (60 575.7 million USD) in 2019 (National Bank of Kazakhstan, 2021).

Following should be taken into the consideration in terms of Chinese presence in China:

- Extreme politicizing of China's presence in Kazakhstan, even BRI is perceived among people as expansionist policy. Only one in six people in Kazakhstan has a positive view of China and is ranked among the unfriendliest countries, increasing the presence in the country, without giving back benefits (Vakulchuk \& Overland, 2019).

- Increase of far-right nationalist tendencies against minorities, including Chinese workers, which has both cultural and economic reasons. Kazakhstani government adopted new law that requires local companies to hire minimum percentage of workers from Kazakhstan and visas with work permit are strict to regulate migration of foreign workers.

- China's oppression in East Turkestan, where Uyghur Turks, including Kazaks and Kirgiz, were put in to the „reeducation camps”, is perceived in Kazakhstan as cultural genocide, creates tensions between China and Kazakhstan.

- "Predatory aid" offering unconditional loans for natural resources mining is locking Kazakhstan in "raw material trap” (Laruelle, 2018). In general, conditions under which China offers its loans, without paying attention to debt sustainability, financing "white elephants", not reporting to OECD or informing public could lead to corruption and worsen debt position of receiver.

\section{Discussion}

From trade perspective the EU is the main trading partner for Kazakhstan accounting for $31.5 \%$ of total Kazakhstan's trade, China is the third largest trading partner (15\%) with a perspective of increasing share in its total trade. On the contrary, the EU's share is declining. Commodity structure of imports from China and the EU to Kazakhstan is similar, exports to the EU consist mainly up of oil and mineral fuels (94\%), exports to China are more diversified, however, mostly compound of raw materials (Table 1). Measuring market (using trade intensity index TII) potential of Kazakhstan on both EU and China markets we came to conclusion, that the intensity of the Kazakh trade with both partners is rather intensive, declining in case of EU since 2014, and on increase with China since 2018. EU trade intensity with Kazakhstan is below expectations, creating room for the increase of trade flows and improvement in the EU foreign trade strategy.

The EU was the largest investor in the country in 2019 (42\%), the share of China was $7 \%$ though the volume is growing since the launch of BRI aligned to "Nurly Zhol" strategy. However, half of the projects is still implemented and planned in petrochemistry sector.

To realise large projects, China is offering loans but, since China has not adopted any antibribery convention, nor is the member of any international arrangements for export credit agencies, the loans lack transparency. In addition, there are concerns about environmental impact of investment projects. On the contrary, EU loans are not only conditional with the commitment of Kazakh government to follow the European requirements on good governance, rule of law, human rights protection, etc. but EU also adheres to international initiatives as a signatory of "OECD agreement OECD Recommendation of the Council on Common Approaches for Officially Supported Export Credits and Environmental and Social Due Dilligence”, that also places limits on financing terms and conditions, "OECD Convention on 
Combating bribery of Foreign Public Officials In International Transactions" (1997) and "OECD Anti-bribery Recommendation” (2009).

China is blamed for predatory development aid aimed at natural sources exploitation and thus locking the country in to the "trap of natural sources". From the EU's point of view Kazakhstan as a middle-income country is not eligible for aid through Development and Cooperation Instrument (DCI). However, is eligible to receive financial and technical assistance through the European Instrument for Democracy and Human Rights (EIDHR), the Instrument contributing to Stability and Peace (IcSP), the Nuclear Safety Instrument, the Partnership Instrument, Development and Cooperation Instrument 2019 new regional programme and through the ERASMUS+ Programme. Kazakhstan has been a major beneficiary of this funding in Central Asia (EEAS, 2020a).

Kazakhstan is perceived as a linchpin of the Eurasia as for the overland part of the BRI initiative (the northern Trans-Siberian corridor) as its geographical location is one of its greatest advantages. There is a possibility of international trade between the EU and China facilitation through railway transport (Czerewacz-Filipowicz, 2019). However, it is limited due to EURussia deteriorated relationship (sanctions imposed by the EU, Russian embargo imposed on European goods). Moreover, the EU de facto has not developed proper relations with the EAEU and this fact creates the biggest problem and barrier to the more successful development of the northern part of BRI as goods traded from China to EU cross only two customs boundaries, the EAEU and the EU. Therefore, establishment of proper relations with EAEU should be perceived as one of the biggest challenges for the EU (Czerewacz-Filipowiz, 2019).

We agree with Cornell and Swanström (2020) that the EU should not rely solely on the power of promoting European values, it should rather focus on its own interests lying in terms of economics and trade, thus clearly define it interests and act as economic power (export market and investor). Thus, it is also important to promote tailor-made approach to Chinese activities in the region, to unit EU members' approach towards Kazakhstan and to define and clarify the EU relations with EAEU is needed.

\section{Conclusion}

The EU as well as China have become important actors in Kazakhstan as well as in the whole Central Asian region. The EU has been the largest trading partner for Kazakhstan, representing more than $30 \%$ of its external trade. Although China's share is only half that of the EU, in context of its growing engagement in the region, the value of mutual trade and its share of Kazakh trade is expected to increase. EU-Kazakhstan relations are also negatively affected by ongoing tensions in EURussia relations. Similarly, the possibility of facilitating trade between the EU and China (via the territory of Kazakhstan) is limited due to the absence of EU policy towards relations with the EAEU.

As for the commodity structure, we can conclude that is very similar for EU and China's exports to Kazakhstan; machinery and electrical equipment account for $40 \%$ of Kazakhstan's imports from both. Whereby most of the exports to the EU consist of mineral fuels, and oils, exports to China are more diversified, with fuels and oils accounting for a third of exports. Based on the TII analysis results, we can conclude that Kazakhstan's trade relations both with the EU and China are intense, whereby according to TII results in 2019, the trade intensity with EU decreased and the intensity in trade with China increased. EU trade intensity index TII with Kazakhstan is below the EU potentiality in terms of EU position in international trade and gives suggestion to reflection on the EU strategy towards Kazakhstan.

As far as investment, the EU accounts for $42 \%$ of FDI inflows to Kazakhstan, thanks to Netherlands ( $71 \%$ of the EU inflows).
China is the fourth largest source of FDI inflows, its investment engagement has intensified in connection to its BRI projects. Energy sector attracted the main share of FDI inflows from the EU and Chinese companies as well. Long term Chinese investments together with coordinated BRI policy and local "Nurly Zhol" strategy may help Kazakhstan to become important transport hub for China in the region as well. Chinese new economic model for the region with investments diversified to several sectors and with participation of local investors gives strong signal to Kazakhstan for long interests of China in the region. However, Kazakhstan has limited diversification of economy and it is questionable if Chinese investments into the infrastructure will boost the development of other sectors. On the other side, the EU approach to Kazakhstan within the new EPCA agreement is not built on the convincing long term investments strategies. To improve the EU trade intensity and investment position the clear policy towards the whole region of EAEU would be a beneficial approach.

\section{Literature:}

1. Aitzhanova, A.: The Belt and Road Initiative: Case of Kazakhstan. [Internet]. 2019. [cited 2021 Feb 18]. Available February from: http://www.emergingmarketsforum.org/wpcontent/uploads/2019/02/Yersultan-Zhanseitovs-presentation.pdf 2. Balás, P., Havlik, P., Cielava, E., Stepanova, A., Komendantova, N., Zaytsev, Y., \& Knobel, A.: Foreign Direct Investment between the EU and EAEU. IIASA Report. Laxenburg, Austria, 2018. 138 p. http://pure.iiasa.ac.at/id/eprint/ $15273 /$

3. Bitabarova, A. G.: Unpacking Sino-Central Asian engagement along the New Silk Road: a case study of Kazakhstan. Journal of Contemporary East Asia Studies, 7 (2), 2018, pp. 149-173. https://doi.org/10.1080/24761028.2018.155 3226

4. Bossuyt, F.: Engaging with Central Asia: China compared to the European Union. In J. Wouters, J.-C. Defraigne, \& M. Burnay (Eds.): China, the European Union and the developing world: a triangular relationship, 2015 (pp. 210-235). Cheltenham, UK: Edward Elgar.

5. Cornell S. E. \& Engvall J.: The EU and Central Asia: Expanding Economic Cooperation, Trade and Investment. 2017. https://www.cacianalyst.org/publications/feature-articles/item/1 3465-the-eu-and-central-asia-expanding-economic-cooperationtrade-and-investment.html

6. Cornell, S. E. \& Swanström, N.: Compatible interests? The EU and China's Belt and Road Initiative. Swedish Institute for European Policy Studies. 202082 https://www.sieps.se/en/publ ications/2020/compatible-interests/

7. Czerewacz-Filipowiz, K.: The Eurasian Economic Union as an Element of the Belt and Road Initiative. Comparative Economic Research. Sciendo, 22(2), 2019, 23-37p. http://doi.org/10.2478/cer-2019-0010

8. EEAS(a): EU-Kazakhstan Cooperation Committee. [Internet]. 2020. [cited 2021 Feb 18]. Available from: https://eeas.europa.eu/headquarters/headquarters-

homepage/85817/eu-kazakhstan-cooperation-committee_en 9. EEAS (b): Kazakhstan and the EU. [Internet]. 2020. [cited 2021 Feb 18]. Available from: https://eeas.europa.eu/delega tions/kazakhstan/1367/kazakhstan-and-eu_en

10. EEC: Agreement on Trade and Economic Cooperation between EAEU and China came into force. [Internet]. 2019. [cited 2021 Feb 18]. Available from: http://www.eurasiancom mission.org/en/nae/news/Pages/25-10-2019-5.aspx

11. European Commission (a): European Union, Trade in goods with Central Asia 5. [Internet]. 2020. [cited 2021 Feb 8]. Available from: https://webgate.ec.europa.eu/isdb_results/fact sheets/region/details_central-asia-5_en.pdf

12. European Commission (b): European Union, Trade in goods with Kazakhstan. [Internet]. 2020. [cited 2021 Feb 8]. Available from:

https://webgate.ec.europa.eu/isdb_results/factsheets/region/detail s_central-asia-5_en.pdf

13. European Commission: Countries and regions. Kazakhstan. [Internet]. 2020. [cited 2021 Feb 9]. Available from: 
https://ec.europa.eu/trade/policy/countries-and-regions/count ries/kazakhstan/

14. European Commission: European Union, Trade in Goods with Kazakhstan. [Internet]. 2021. [cited 2021 Jan 23]. Available from: https://webgate.ec.europa.eu/isdb_results/factsheets/cou ntry/details_kazakhstan_en.pdf

15. Fehér, I., Fieldsend, A. F.: The potential for expanding wheat production in Kazakhstan. Analysis from a food security perspective. Publications Office of the European Union, Luxembourg, 2019, ISBN 978-92-79-96386-5, doi: 10.276 0/487249.

16. ITC: Trade Map: Trade statistics for international business development. [Internet]. 2021. [cited 2021 Feb 16]. Available from: https://www.trademap.org/Index.aspx

17. Kaštáková, E. \& Barinková, N.: Development of foreign trade relations between Kazakhstan and the EU under the influence of geopolitical changes. Central and Eastern Europe in the Changing Business Environment: Proceedings. Vydavatel'stvo EKONÓM, 2019, pp. 113-123.

18. Kašt’áková, E., Drieniková, K. \& Zubal'ová, L.: Impact of the geopolitical changes on the EU foreign trade relations with selected territories: Implications for the Slovak economy. Saint Petersburg University Press. 2019. ISBN 978-5-288-05988-9.

19. Kazakh Invest: Construction of Kazakh-Chinese investment projects will be carried out in accordance with the legislation of Kazakhstan. [Internet]. 2019. [cited 2021 Jan 21]. Available from: https://invest.gov.kz/media-center/press-releases/stroitel stvo-kazakhstansko-kitayskikh-invest-proektov-budet-vestis-vsootvetstvii-s-zakonodatelstvom/

20. Kazakhembus.com: Nurly Zhol - The Path to The Future. [Internet]. n. d. [cited 2021 Feb 18]. Available from: https://kaz akhembus.com/domestic-policy/modernization-programs/nurlyzhol

21. Kley, D.: China diversifies in Central Asia. [Internet]. 2020. [cited 2021 Jan 23]. Available from: https://eurasianet.org/chinadiversifies-in-central-asia

22. Konopelko, A.: Eurasian Economic Union: a challenge for EU policy towards Kazakhstan. In Asia Europe Journal, 16, 2018, 1-17. https://doi.org/10.1007/s10308-017-0480-7

23. Laruelle, M. (Ed.): China's Belt and Road Initiative and its Impact in Central Asia. The George Washington University, Central Asia Program 2018.

24. Mardell, J.: China's footprint in Central Asia. [Internet]. Bertelsmann Policy Brief August 2020. [Internet]. 2020. [cited 2021 Jan 23]. Available from: https://www.bertelsmannstiftung.de/en/our-projects/germany-and-asia/news/asia-policybrief-chinas-footprint-in-central-asia

25. Nabiyeva, K.: Win-win or win-lose. China-Kazakhstan energy cooperation within the Belt and Road Initiative. [Internet]. 2019. [cited 2021 Feb 2]. Available 2 from: https://crossasia-repository.ub.uni-heidelberg.de/4176/1/Blickw echsel_ChinaKazakhstan_Energy_Cooperation_within_the_Belt and_Road_Initiative.pdf

26. National Bank of Kazakhstan: External debt. [Internet]. 2021. [cited 2021 Feb 8]. Available from: https://old.natio nalbank.kz/?docid=202\&switch=english

27. National Bank of Kazakhstan: Direct Investments according to the directional principle. External Debt. [Internet]. 2021. [cited 2021 Feb 17]. Available from: https://nationalbank .kz/en/news/pryamye-investicii-po-napravleniyu-vlozheniya / https://nationalbank.kz/en/news/vneshniy-dolg

28. Pantucci, R.: China in Central Asia: The first strand of the Silk Road Economic Belt. Asian Affairs, 50 (2), 2019. 205-215p. https://doi.org/10.1080/03068374.2019.1622930

29. Pieper, M.: The linchpin of Eurasia: Kazakhstan and the Eurasian Economic Union between Russia's defensive regionalism and China's new Silk Roads. International Politics, 11 May 2020. https://doi.org/10.1057/s41311-020-00244-6

30. Shakhanova, G. Garlick, J.: The Belt and Road Initiative and the Eurasian Economic Union: Exploring the "Greater Eurasian Partnership”. Journal of Current Chinese Affairs, 49(1), 2020, 33-57. DOI: 10. 1177/ 1868102620911666

31. TradeMap database. [Internet]. 2021. [cited 2021 Feb 1]. Available from: https://www.trademap.org/Bilateral_TS.aspx?nv $\mathrm{pm}=1 \% 7 \mathrm{c} 398 \% 7 \mathrm{c} \% 7 \mathrm{c} 156 \% 7 \mathrm{c} \% 7 \mathrm{cTOTAL} \% 7 \mathrm{c} \% 7 \mathrm{c} \% 7 \mathrm{c} 2 \% 7 \mathrm{c1}$ \%7c1\%7c1\%7c2\%7c1\%7c1\%7c1\%7c1\%7c1
32. UNCTAD: World Investment Report 2020. International production beyond the pandemic. 2020 https://doi.org/ 10.18356/920f7642-en

33. Vakulchuk, R. \& Overland, I.: China's Belt and Road Initiative through the lens of Central Asia. In F. M. Cheung \& Y. Hong (Eds.), Regional Connection under the Belt and Road Initiative: The Prospect for Economic and Financial Cooperation. 2019. (pp. 115-133). Routledge. DOI: 10.43 24/9780429467172-5

34. Vanderhill, R., Joireman, S. F. \& Tulepbayeva, R.: Between the bear and the dragon: multivectorism in Kazakhstan as a model strategy for secondary powers. In International Affairs, 96(4), 2020, 975-993. https://doi.org/10.1093/ia/iiaa061

35. World Bank: Trade Indicators. [Internet]. 2010. [cited 2021

Jan 14]. Available from: https://wits.worldbank.org/wits/wits/ witshelp/Content/Utilities/e1.trade_indicators.htm

36. World Bank: Online Trade Outcomes Indicators - User's Manual. [Internet]. 2013. [Internet]. 2020. [cited 2021 Jan 14]. Available from: http://wits.worldbank.org/WITS/docs/TradeO utcomes-UserManual.pdf

37. Yergaliyeva, A.: FDI to Central Asia Reached 378.2 billion Over Past 13 years. [Internet]. 2020. [cited 2021 Jan 16]. Available from: https://astanatimes.com/2020/12/fdi-to-centralasia-reached-378-2-billion-over-past-13-years/

38. Yesdauletov, A., Oralov, A., Turkhanova, A., Yesdauletov, I., Tuleshova, L., \& Yesdauletova, A.: A new stage of relations between the European union and Kazakhstan: Europeanization process. Astra Salvensis, 5(10), 2017, 77-90.

39. Zogg, B.: Kazakhstan: A Centrepiece in China's Belt and Road. CSS Analyses. Security Policy No. 249, September 2019, https://doi.org/10.3929/ethz-b-000362184

\section{Primary Paper Section: A}

Secondary Paper Section: AH 